\title{
Small business incubators: An emerging phenomenon in South Africa's SMME economy
}

\author{
Mukovhe Masutha \\ Christian M. Rogerson
}

\begin{abstract}
Mukovhe Masutha, University of Johannesburg, Faculty of Science, School of Geography, Environmental Management \& Energy Studies, South Africa (masutham@thusananifoundation.co.za)
\end{abstract}

Christian M. Rogerson, University of Johannesburg, Faculty of Management, School of Tourism \& Hospitality, South Africa (crogerson@uj.ac.za)

\begin{abstract}
In South Africa much policy attention is focused on the potential of the small, medium and micro-enterprise (SMME) economy for job creation. Nevertheless, despite government support for the SMME economy, high mortality rates are experienced by start-up enterprises. In common with international experience South Africa has adopted business incubation as a strategic tool for assisting the survival as well as building the competitiveness of SMMEs. This article analyses the state of business incubation in South Africa drawing attention to marked differences between the groups of public sector business incubators as opposed to those business incubators which have been initiated by the private sector.
\end{abstract}

Keywords: small business development, SMMEs, South Africa, business incubators

\section{Introduction}

Two decades after the democratic transition South Africa remains one of the most unequal societies in the world (Ndungu \& Frye, 2008). Some observers argue that poverty, unemployment and inequality levels have reached a state of crisis and threaten the social and economic stability of one of Africa's youngest democracies (Fakir, 2009). In a response to the triple challenge of poverty, unemployment and inequality the South African government has made substantial commitments to supporting Small, Medium and Micro Enterprises (SMMEs) as a critical policy vehicle for achieving sustainable economic growth, creating employment opportunities and alleviating poverty (Department of Trade and Industry [DTI], 1995, 2006; Rogerson, 2013). It is significant that the national government's New Growth Path (NGP) and the National Development Plan (NDP), South Africa's blueprint for future development, both identify the SMME sector as central to the realization of South Africa's Vision 2030. The National Development Plan Vision 2030 sets out a target of creating 11 million jobs by 2030, of which 90 percent is expected to come from SMMEs (Department of Economic Development, 2011; National Planning Commission, 2011). In addition, the promotion and growth of SMMEs is one of the cornerstones for the successful attainment of local economic development programming in South Africa (Rogerson, 2006, 2007, 2008a, 2010, 2011, 2012, 2014; Rogerson \& Rogerson, 2010a, 2012). The establishment of a network of business incubators is an essential step for improving the local business environment and enhancing prospects for local development particularly in South Africa's urban areas (Rogerson \& Rogerson, 2010b, 2011, 2012). Overall, the importance attached by national government to the role of small businesses is underlined by the establishment during 2014 of a separate dedicated Ministry of Small Businesses (Greve, 2014). 
Despite the long-standing government commitment and increased support for the sector South African SMMEs have not reached their intended impact, anticipated or desired by policymakers (Rogerson, 2004, 2008b; Timm, 2012). Rather, the South African SMME economy continues to experience high mortality rates with SMMEs failing to grow sufficiently to create the expected employment opportunities (Herrington et al., 2008, 2009, 2010, 2011). The 2011 report produced by the Global Entrepreneurial Monitor (GEM) rated South Africa's total early-stage entrepreneurial activity at 9.1 percent. Arguably, this rating of South Africa's early-stage entrepreneurial activity remains far lower than that of comparable emerging economies such as Brazil, Chile or Malaysia (Herrington et al., 2011; Timm, 2012). The GEM report (2011) further notes that South Africa has one of the world's lowest SMME survival rates. Indeed, in 2012, the country's Small Enterprise Development Agency (SEDA) estimated that 80 percent of South Africa's SMMEs are failed businesses in their first year of existence (SEDA, 2012).

Across both developed and developing countries small business incubators have been identified as strategic tools for helping to grow a country's entrepreneurial base while reducing the high mortality of SMMEs. Although the detailed definition of small business incubator is contested there is a general consensus among scholars that a business incubator provides various targeted business support and technical support services aimed at growing emerging and small start-up business enterprises into financially and operationally independent enterprises (Akcomak, 2009; InfoDev, 2010a). Business incubation has been adopted and supported for varying reasons in several countries (Akcomak, 2009; Monkman, 2010; Barbero et al., 2012). Governments across both developed and developing countries have adopted and supported business incubation within various developmental contexts and in response to different developmental challenges (InfoDev, 2010a; Monkman, 2010). Although the reasons behind the establishment of business incubators appear similar, often each nation has specific priorities which respond to locally-specific challenges (InfoDev, 2010a). This said, the most common motives for governments to give support for business incubator programmes relate to issues of employment creation, poverty alleviation, technology transfer, acceleration of business growth, reduction of the mortality rate of SMMEs, empowerment of specific groups of entrepreneurs, creating value for various stakeholders, urban/rural regeneration, and the revitalization of local economies (Colombo \& Delmastro, 2002; Monkman, 2010). For Akcomak (2009: 1) incubators provide an attractive framework for government policymakers and "can be considered as a remedy for the disadvantages that small and new firms encounter by providing numerous business support services and they are useful in fostering technological innovation and industrial renewal”.

Notwithstanding growing international interest for the application of small business incubators, research concerning business incubation is limited and remains in its infancy. In common with the international experience South Africa, through the Department of Trade and Industry (DTI), has identified business incubation as a viable tool to help SMMEs grow and become successful and globally competitive enterprises with the potential to create jobs, alleviate poverty, empower previously marginalized groups and contribute to the growth of local economies (InfoDev, 2010b; SEDA, 2010; Timm, 2012, DTI, 2013). The lead agency for galvanizing business incubation is the government's Small Enterprise Development Agency or SEDA. In South Africa only a small number of investigations have been undertaken on the role of business incubators as one of the ways in which the country might seek to energize its entrepreneurial base for developmental purposes (Wyeth, 2007; Buys \& Mbewana, 2007; Ndabeni, 2008; InfoDev, 2010b; Sandheep \& Thomas, 2011). Accordingly, there is a significant knowledge gap concerning business incubation in the country and in particular, little is known about the organization and operations of different kinds of business incubators (Masutha, 2014). The aim in this paper is to address this knowledge deficit about 
the growing phenomenon of small business incubators in South Africa. More specifically, the discussion undertakes an analysis of the contemporary state of business incubators, their sectoral and institutional base, and character of entrepreneurs. The conclusion seeks to draw comparisons and differences between the groups of public and private incubators in South Africa.

The analysis is based upon a national audit that was undertaken of business incubator operations in South Africa during 2013. In addition, it draws upon findings from a national survey of business incubators, documentary sources in the form of SEDA Annual Reports and material gathered from semi-structured interviews conducted with the SEDA Technology Programme Executive Manager, former SEDA Technology Programme Executive Managers, SEDA Regional Manager (Gauteng) and telephonic interviews with incubator managers of both public and private sector business incubators. In total, responses were received from thirty-eight of the forty-two public incubators implying a response level of 90 percent. Information concerning the remaining four public sector incubators was received during an interview with the SEDA Regional manager responsible for incubation. In the private sector, responses were received from seven of the nine private sector business incubators in the country which is a 78 percent response rate.

\section{National State of Business Incubators}

In terms of numbers of incubators by 2013 the audit of national incubators reveals a total of 51 functioning incubators. This figure represents a marked growth in the numbers of South African business incubators from a total of only four in 2004, to 37 by 2011 to 51 by 2013. The majority of the 51 business incubators have been established by the public sector. Of the national total of incubators 42 or 82 percent are public sector driven through the activities of SEDA, South Africa's national small enterprise development agency. The remaining nine incubators or 18 percent are private sector operations. Overall, it was disclosed in interviews that the primary objective of public sector incubators is to broaden economic participation in South Africa by creating employment opportunities and the transference of skills, most importantly for disadvantaged communities. By contrast most private sector incubators focus upon growing small businesses into assets of value with specific emphasis on maximizing the profitability and annual turnover of the small business. In terms of the incubators' institutional environment, all public incubators report to the Department of Trade and Industry's Small Enterprise Development Agency, while private incubators are accountable to their parent companies. Within the international landscape of business incubators it is apparent that the public sector has been particularly strong in driving the growth trajectory of the business incubator movement in South Africa (SEDA, 2010, 2011a, 2011b; 2012). Indeed, it is only in recent years that a set of parallel private sector incubators have made their appearance.

Table 1: Number of Incubators by Sector

\begin{tabular}{ll}
\hline Sectoral Focus & Number of Incubators \\
\hline Manufacturing & 13 \\
Mixed Use & 8 \\
Agriculture/Agro-Processing & 7 \\
Construction & 5 \\
ICT & 5 \\
Chemicals & 4 \\
Jewellery & 4 \\
Small-scale Mining & 2 \\
Bio and Life Science & 1
\end{tabular}


Renewable Energy 1

Automotive

1

(Source: Authors)

Table 1 shows the sectoral focus of business incubators in South Africa. A number of points can be observed. First, 84 percent of business incubators (43 in total) are sectorally specific and only 8 incubators can be described as mixed in terms of the business category of incubatees. Second, in terms of sectoral focus, currently the largest number of functioning incubators are linked to manufacturing with the largest individual sectors being those of furniture, agro-processing and chemicals. Other manufacturing activities in which sector specific incubators have been established include the production of jewellery, aluminum fabrication, and stainless steel. Three, beyond manufacturing-linked incubators there are several incubators which are dedicated to support other sectors such as ICT, construction and small-scale mining. Finally, in agriculture there are incubators which support enterprise development for both floriculture and the production of essential oils.

Table 2: Number of Incubators in Each Sector: Public vs Private Sector Driven

\begin{tabular}{lll}
\hline Sectoral Focus & Public Sector & Private Sector \\
\hline Manufacturing & 13 & 0 \\
Mixed Use & 2 & 6 \\
Agriculture/Agro-Processing & 7 & 0 \\
Construction & 5 & 0 \\
ICT & 3 & 2 \\
Chemicals & 3 & 1 \\
Jewellery & 4 & 0 \\
Small-scale Mining & 2 & 0 \\
Bio and Life Science & 1 & 0 \\
Renewable Energy & 1 & 0 \\
Automotive & 1 & 0 \\
\hline (Source: Author) & &
\end{tabular}

(Source: Authors)

Table 2 reveals the sectoral distribution or focus of respectively the groups of public sector versus private sector incubators. It is evident that significant differences between the focus of public sector as opposed to private sector operated business incubators in South Africa. Three points are of note. First, 95 percent of public sector incubators are sectorspecific with only two of the 42 incubators functioning as mixed incubators. Second, by contrast, two-thirds of the private sector incubators are mixed and only three sector-dedicated incubators have been initiated by the private sector. Third, of the large group of public sector incubators initiated by SEDA, the majority are linked to manufacturing activities or agroprocessing.

Table 3: Number of Incubators by Province

\begin{tabular}{ll}
\hline Province & Number of Incubators \\
\hline Gauteng & 17 \\
KwaZulu-Natal & 12 \\
Eastern Cape & 7 \\
Western Cape & 5 \\
Mpumalanga & 5 \\
Limpopo & 2 \\
Free State & 1
\end{tabular}


North West 1

Northern Cape 1

(Source: Authors)

Finally, in terms of their geographical distribution across South Africa, a number of points can be observed. As is demonstrated on Table 3 at least one business incubator has been established in each of South Africa's nine provinces. However, the largest clusters of business incubators are currently located in the provinces of Gauteng and KwaZulu-Natal followed by Eastern Cape, Western Cape and Mpumalanga. Together these five provinces account for 90.2 percent of all business incubators. The provinces that are relatively underserved in terms of business incubators are Limpopo, North West, Free State and Northern Cape.

Table 4: Geographic Distribution of Business Incubators by Settlement Type

\section{Number of Business \% Share}

Incubators

\begin{tabular}{lll}
\hline Urban Areas - & 41 & 80 \\
Cities/Small Towns/Cities & & \\
Townships & 5 & 10 \\
Rural Areas & 5 & 10
\end{tabular}

(Source: Authors)

Table 4 provides a more refined picture of the location of business incubators in terms of different types of settlement. This reveals that South African business incubators are unevenly distributed between urban and rural areas. Over half of the existing business incubators are located in South Africa's leading metropolitan centres with Johannesburg having the greatest individual number of incubators. It is observed that all the private sector business incubators are situated in metropolitan areas and that the private sector driven incubators are absent from secondary cities or small towns. The geography of public sector incubators reveals, however, an outreach into secondary cities and small towns. Importantly, however, there are few business incubators located in the underdeveloped rural areas or urban townships, the most disadvantaged areas of the South African space economy.

\section{Survey Findings}

The national survey of public and private incubators collected information on a number of different aspects of their operations. In particular, information was obtained on the evolution and size of incubators, nature of SMMEs, number of jobs created, and issues of recruitment and graduation of incubatees.

Table 5: Number of Public Sector Business Incubators by years of establishment

\begin{tabular}{ll}
\hline $\begin{array}{l}\text { Year of } \\
\text { establishment }\end{array}$ & $\begin{array}{l}\text { Number of Incubators } \\
\text { Established }\end{array}$ \\
\hline 2001 & 3 \\
2002 & 2 \\
2003 & 1 \\
2004 & 5 \\
2005 & 4 \\
2006 & 4 \\
2007 & - \\
2008 & 3 \\
2009 & 6
\end{tabular}




\begin{tabular}{ll}
2010 & 2 \\
2011 & 1 \\
2012 & 11 \\
\hline Total & 42 \\
\hline
\end{tabular}

(Source: Authors)

Table 6: Number of Private Sector Business Incubators by years of establishment

\begin{tabular}{ll}
\hline $\begin{array}{l}\text { Year of } \\
\text { establishment }\end{array}$ & $\begin{array}{l}\text { Number of Incubators } \\
\text { Established }\end{array}$ \\
\hline 2000 & 2 \\
2001 & 1 \\
2002 & - \\
2003 & - \\
2004 & 1 \\
2005 & 1 \\
2006 & - \\
2007 & - \\
2008 & 1 \\
2009 & 1 \\
2010 & 1 \\
2011 & 1 \\
2012 & - \\
\hline
\end{tabular}

(Source: Authors)

Tables 5 and 6 provide a profile of the evolution of business incubators in South Africa, both private and public, by year of establishment. It is evident that South Africa's business incubation movement has evolved rapidly particularly over the past decade. In 2001 there existed only 3 public incubators in South Africa. Between 2001 and 2007 this number increased to 20 public incubators. During the past 5 years South Africa has expanded the number of public incubators from 20 in 2007 to reach a total of 42 by 2012. In 2012 SEDA established 11 public sector incubators. Tables 5 and 6 indicate that the category of public sector incubators has evolved more rapidly than private sector incubators in terms of number of incubators established each year.

Table 7: Number of SMMEs Currently Supported by Public Sector Incubators

\begin{tabular}{|c|c|c|}
\hline Name of Public Business Incubator & $\begin{array}{l}\text { Number of SMMEs } \\
\text { Currently Supported }\end{array}$ & $\begin{array}{l}\text { Incubation } \\
\text { Model }\end{array}$ \\
\hline Chemin (3 Incubation Centers) & 50 & Physical \\
\hline $\begin{array}{l}\text { Downstream Aluminium Centre for Technology } \\
\text { (DACT) }\end{array}$ & 76 & Physical \\
\hline EgoliBio & 13 & Physical \\
\hline Ekurhuleni Jewellery Incubator & New & Physical \\
\hline Furntech (7 Incubation Centers) & 93 & Mixed \\
\hline Global Jewellery Academy & 6 & Physical \\
\hline $\begin{array}{l}\text { Innovation Technology Business Incubator (Invo } \\
\text { Tech) }\end{array}$ & 33 & Physical \\
\hline Lepharo & 6 & Physical \\
\hline Mapfura Makhura Incubator (MMI) & 166 & Virtual \\
\hline Mpumalanga Agri-skills Development \& Training & 131 & Virtual \\
\hline
\end{tabular}


(MASDT), Nelspruit

Mpumalanga Stainless Steel Initiative (MSI) 34

Physical

Seda Agricultural \& Mining Tooling Incubator 24

Physical

(SAMTI)

Seda Alfred Nzo Agro Manufacturing Incubator New

Physical

(SANAMI)

Seda Atlantis Renewable Business Incubator New

Physical

(SEREBI)

Seda Automotive Technology Centre (SATEC) 45

Seda Construction Incubator (SCI) 215

Physical

Seda Essential Oils Business Incubator (SEOBI) 68

Virtual

(2 Incubation Centers)

Seda Limpopo Jewellery Incubator (SLJI) 80

Physical

Seda Nelson Mandela Bay ICT Incubator 30

Physical

(SNMBICTI)

Seda Northern Cape Diamond and Jewellery New

Physical

Incubator

Seda Platinum Incubator (SPI) 33

Physical

Seda Sugar Cane Incubator SESUCI) 105

Physical

Seed Container Park (Secopa) 7

SmartExchange

7 Physical

SoftstartBTI (SBTI)

47

44

Physical

Soshanguve Manufacturing Technology 60

Mixed

Demonstration Centre (SMTDC)

Timbali

118

Physical

Zenzele Technology Demonstration Centre

30

Virtual

Total 1514

Physical

(Source: Authors)

Table 8: Number of SMMEs Currently Supported by Private Sector Incubators

\begin{tabular}{lll}
\hline Name of Private Business Incubator & $\begin{array}{l}\text { Number of SMMEs } \\
\text { Currently } \\
\text { Supported (2012) }\end{array}$ & Incubation Model \\
\hline Raizcorp Business Incubator & 300 & Virtual \\
Aurik Business Incubator & 200 & Virtual \\
Bandwidth Barn ICT Incubator & 70 & Physical \\
Shanduka Black Umbrellas (JHB) & 29 & Mixed \\
Shanduka Black Umbrellas (CT) & 17 & Mixed \\
Shanduka Black Umbrellas (PTA) & 18 & Mixed \\
Shanduka Black Umbrellas (DBN) & 24 & Mixed \\
Sasol Chemcity Business Incubator & 179 & Virtual \\
\hline Total & 837 & \\
\hline
\end{tabular}

(Source: Authors)

Tables 7 and 8 reveal the numbers of SMMEs currently supported in respectively public incubators and private incubators. It is evident that there are considerable variations in the size of various incubators as measured by the number of SMMEs currently supported. In the case of public sector incubators, excluding newly established incubators (that currently have no occupants), the range in size is from six to 215 in total. The largest cluster of public sector 
incubators is, however, in the range of 40 to 80 SMMEs. In examining Table 5 it is evident that the size of private incubators is considerably larger than public sector incubators. The survey revealed a range of sizes from 17 SMMEs in an incubator with the lowest number of SMMEs to 300 in the case of Raizcorp. Currently, the average incubator size for public incubators is calculated as 44 SMMEs, whereas the average size for private incubators is 97 SMMEs per incubator. With the growing demand of business incubation services, both groups of public and private sector incubators are progressively introducing programmes of virtual incubation as opposed to a physical incubator. The group of private sector incubators is already predominantly virtual in their operational model. A major advantage of virtual business incubation is that it increases incubators' capacity to accommodate more SMMEs. It is evident that marked size differences exist between the groups of physical as opposed to virtual incubators. Nationally, the largest physical incubator had 64 SMMEs. The largest incubator is a virtual rather than physical incubator (Raizcorp Business Incubator) with 300 SMMEs.

Table 9: Percentage of Women-Owned SMMEs by Business Incubator

\begin{tabular}{|c|c|}
\hline Name of Business Incubator & \% Women Owned \\
\hline Chemin (3 Incubation Centers) & 100 \\
\hline Downstream Aluminium Centre for Technology (DACT) & 45 \\
\hline EgoliBio & 58 \\
\hline Ekurhuleni Jewellery Incubator & 0 \\
\hline Furntech (7 Incubation Centers) & 39 \\
\hline Global Jewellery Academy & New \\
\hline Innovation Technology Business Incubator (Invo Tech) & 3 \\
\hline Lepharo & 38 \\
\hline Mapfura Makhura Incubator (MMI) & 22 \\
\hline $\begin{array}{l}\text { Mpumalanga Agri-skills Development \& Training (MASDT), } \\
\text { Nelspruit }\end{array}$ & 36 \\
\hline Mpumalanga Stainless Steel Initiative (MSI) & 17 \\
\hline Seda Agricultural \& Mining Tooling Incubator (SAMTI) & 4 \\
\hline Seda Alfred Nzo Agro Manufacturing Incubator (SANAMI) & New \\
\hline Seda Atlantis Renewable Business Incubator (SEREBI) & New \\
\hline Seda Automotive Technology Centre (SATEC) & 7 \\
\hline Seda Construction Incubator (SCI), & 43 \\
\hline Seda DUT Technology Incubator (SDTI) & New \\
\hline $\begin{array}{l}\text { Seda Essential Oils Business Incubator (SEOBI) (2 Incubation } \\
\text { Centers) }\end{array}$ & 44 \\
\hline Seda Limpopo Jewellery Incubator (SLJI) & 57 \\
\hline Seda Nelson Mandela Bay ICT Incubator (SNMBICTI) & New \\
\hline Seda Northern Cape Diamond and Jewellery Incubator & New \\
\hline Seda Platinum Incubator (SPI) & 37 \\
\hline Seda Sugar Cane Incubator SESUCI) & 33 \\
\hline Seed Container Park (Secopa) & 75 \\
\hline SmartExchange & 23 \\
\hline SoftstartBTI (SBTI) & 16 \\
\hline $\begin{array}{l}\text { Soshanguve Manufacturing Technology Demonstration Centre } \\
\text { (SMTDC) }\end{array}$ & 33 \\
\hline Timbali & 100 \\
\hline
\end{tabular}


Zenzele Technology Demonstration Centre 24

\begin{tabular}{ll}
\hline Total & 40 \\
\hline
\end{tabular}

(Source: Authors)

Table 10: Percentage of Black-Owned SMMEs by Business Incubator

\begin{tabular}{|c|c|}
\hline Name of Business Incubator & \% Black-Owned \\
\hline Chemin (3 Incubation Centers) & 100 \\
\hline Downstream Aluminium Centre for Technology (DACT) & 36 \\
\hline EgoliBio & 67 \\
\hline Ekurhuleni Jewellery Incubator & New \\
\hline Furntech (7 Incubation Centers) & 91 \\
\hline Global Jewellery Academy & 100 \\
\hline Innovation Technology Business Incubator (Invo Tech) & 95 \\
\hline Lepharo & 100 \\
\hline Mapfura Makhura Incubator (MMI) & 100 \\
\hline Mpumalanga Agri-skills Development \& Training (MASDT), Nelspruit & 100 \\
\hline Mpumalanga Stainless Steel Initiative (MSI) & 48 \\
\hline Seda Agricultural \& Mining Tooling Incubator (SAMTI) & 88 \\
\hline Seda Alfred Nzo Agro Manufacturing Incubator (SANAMI) & New \\
\hline Seda Atlantis Renewable Business Incubator (SEREBI) & New \\
\hline Seda Automotive Technology Centre (SATEC) & 100 \\
\hline Seda Construction Incubator (SCI), & 100 \\
\hline Seda DUT Technology Incubator (SDTI) & New \\
\hline Seda Essential Oils Business Incubator (SEOBI) (2 Incubation Centers) & 100 \\
\hline Seda Limpopo Jewellery Incubator (SLJI) & 100 \\
\hline Seda Nelson Mandela Bay ICT Incubator (SNMBICTI) & 89 \\
\hline Seda Northern Cape Diamond and Jewellery Incubator & New \\
\hline Seda Platinum Incubator (SPI) & 92 \\
\hline Seda Sugar Cane Incubator SESUCI) & 100 \\
\hline Seed Container Park (Secopa) & 100 \\
\hline SmartExchange & 100 \\
\hline SoftstartBTI (SBTI) & 34 \\
\hline Soshanguve Manufacturing Technology Demonstration Centre (SMTDC) & 100 \\
\hline Timbali & 100 \\
\hline Zenzele Technology Demonstration Centre & 100 \\
\hline Total & 83 \\
\hline
\end{tabular}

(Source: Authors)

Tables 9 and 10 index the proportion of women owned SMMEs by business incubators and black owned SMMEs by incubators. The analyses relate only to public sector incubators, as private sector incubators could not provide this information. In terms of the proportion of women owned SMMEs, considerable variations exist. Table 9 reveals that on average women owned SMMEs represent 40 percent of the public sector incubatees. This said, in some cases the proportion is less than 10 percent and in other instances it reaches 100 percent as in the case of Timbali Floriculture business incubator and Chemin business incubator. Table 10 discloses that the vast majority of public sector incubators are supporting only black owned SMMEs. This is in line with the objectives of the business incubator programme as laid out 
by the Department of Trade and Industry to give preference to disadvantaged groups. The emphasis upon black owned and women owned enterprises within the group of public incubators reflects the recruitment strategies for these incubators. The survey revealed that common recruitment strategies by the public sector include the hosting of networking events such as incubation days, advertisements including radio, television and lampposts, the hosting of roadshows, use of websites, social networks (Facebook), walk-ins and referrals. Overall, a key finding from the survey was that each incubator developed its own individual recruitment strategy to attract a particular group of aspiring entrepreneurs.

It is significant to observe that incubators have aligned their SMME recruitment strategies to their respective incubation models and objectives. For example, the private sector Shanduka Black Umbrellas Business Incubator (SBU) recruitment strategy targets enterprises that are 100 percent black owned. This is in line with the incubator's strategic objective to broaden economic participation in South Africa by empowering emerging black entrepreneurs and their SMMEs. The survey also reveals that most incubators have aligned their SMME recruitment strategies with specific sectors of the economy. For example, Softstart Business Technology incubator only recruits entrepreneurs in the Information and Communications (ICT) sector.

Table 11: Number of Jobs Created by Public Business Incubators (2012)

\begin{tabular}{lll}
\hline Name of Business Incubator & $\begin{array}{l}\text { Number } \\
\text { Created }\end{array}$ & Jobs \\
\hline Chemin (3 Incubation Centers) & 68 \\
Downstream Aluminium Centre for Technology (DACT) & 52 \\
EgoliBio & 45 \\
Ekurhuleni Jewellery Incubator & New \\
Furntech (7 Incubation Centers) & 80 \\
Global Jewellery Academy & 0 \\
Innovation Technology Business Incubator (Invo Tech) & 57 \\
Lepharo & 42 \\
Mapfura Makhura Incubator (MMI) & 68 \\
Mpumalanga Agri-skills Development $\quad$ \& Training $\quad$ (MASDT), & 80 \\
Nelspruit & \\
Mpumalanga Stainless Steel Initiative (MSI) & 11 \\
Seda Agricultural \& Mining Tooling Incubator (SAMTI) & 20 \\
Seda Alfred Nzo Agro Manufacturing Incubator (SANAMI) & New \\
Seda Atlantis Renewable Business Incubator (SEREBI) & New \\
Seda Automotive Technology Centre (SATEC) & 12 \\
Seda Construction Incubator (SCI) & 1050 \\
Seda Essential Oils Business Incubator (SEOBI) (2 Incubation & 154 \\
Centers) & \\
Seda Limpopo Jewellery Incubator (SLJI) & 17 \\
Seda Nelson Mandela Bay ICT Incubator (SNMBICTI) & 35 \\
Seda Northern Cape Diamond and Jewellery Incubator & New \\
Seda Platinum Incubator (SPI) & 23 \\
Seda Sugar Cane Incubator SESUCI) & 59 \\
Seed Container Park (Secopa) & 47 \\
SmartExchange & 55 \\
SoftstartBTI (SBTI) & 29 \\
\hline &
\end{tabular}


Soshanguve Manufacturing Technology Demonstration Centre 25 (SMTDC)

Timbali

Zenzele Technology Demonstration Centre

Total

(Source:Authors)

Table 12: Number of Jobs Created by Private Business Incubators

\begin{tabular}{ll}
\hline Name of Private Business Incubator & Number of Jobs Created \\
\hline Raizcorp Business Incubator & No Records \\
Aurik Business Incubator & No Records \\
Shanduka Black Umbrellas (Johannesburg) & 50 \\
Shanduka Black Umbrellas (Cape Town) & 30 \\
Shanduka Black Umbrellas (Pretoria) & 46 \\
Shanduka Black Umbrellas (Durban) & 40 \\
Sasol Chemcity Incubator & 3099 \\
\hline Total & Not available \\
\hline (Source: Authors) &
\end{tabular}

Tables 11 and 12 present data provided on the number of jobs which were created by each of the incubators respectively for the public sector incubators (Table 11) and the private sector incubators (Table 12). It should be noted that information for the private sector business incubators could not be obtained from two of the seven surveyed incubators. A key finding is the much greater impact for job creation of the group of private sector incubators. It is evident that the number of jobs created by several of the private sector incubators is in excess of all the jobs created in total by the group of public sector incubators. By the end of the 2012 financial year, in total the number of jobs created by public sector incubators stood at 2031 jobs, whereas the group of four private incubators from which information is available together created at least 3099 jobs. This finding points to the markedly different job creating impact of private sector business incubators as opposed to the group of public sector incubators.

Table 13: Number of Graduates from Public Sector Business Incubators

\begin{tabular}{|c|c|c|c|c|}
\hline $\begin{array}{l}\text { Name of Public } \\
\text { Business Incubator }\end{array}$ & $\begin{array}{l}\text { Founding } \\
\text { Year }\end{array}$ & $\begin{array}{l}\text { Number } \\
\text { Graduates } \\
\text { Inception }\end{array}$ & $\begin{array}{r}\text { of } \\
\text { Since }\end{array}$ & $\begin{array}{l}\text { Graduation } \\
\text { Period }\end{array}$ \\
\hline Chemin (3 Incubation Centers) & 2002 & 30 & & 3 Years \\
\hline $\begin{array}{l}\text { Downstream Aluminium Centre for } \\
\text { Technology (DACT) }\end{array}$ & 2002 & 20 & & 3 Years \\
\hline EgoliBio & 2001 & No Records & & 3 Years \\
\hline Ekurhuleni Jewellery Incubator & 2009 & No Records & & 3 Years \\
\hline Furntech (7 Incubation Centers) & 2001 & 85 & & 3 Years \\
\hline Global Jewellery Academy & 2009 & No Records & & 3 Years \\
\hline $\begin{array}{l}\text { Innovation } \quad \text { Technology } \quad \text { Business } \\
\text { Incubator (Invo Tech) }\end{array}$ & 2009 & 5 & & 3 Years \\
\hline Lepharo & 2009 & No Records & & 3 Years \\
\hline Mapfura Makhura Incubator (MMI) & 2006 & 50 & & 3 Years \\
\hline Mpumalanga Agri-skills Development \& & 2005 & 51 & & 3 Years \\
\hline
\end{tabular}

Training (MASDT), Nelspruit 
Mpumalanga Stainless Steel Initiative 2001

3 Years (MSI)

Seda Agricultural \& Mining Tooling 2010

New

3 Years

Incubator (SAMTI)

Seda Alfred Nzo Agro Manufacturing 2012

New

3 Years

Incubator (SANAMI)

Seda Atlantis Renewable Business 2012

New

3 Years

Incubator (SEREBI)

Seda Automotive Technology Centre 2011 (SATEC)

Seda Construction Incubator (SCI) (5 2006 Incubation centers)

Seda DUT Technology Incubator (SDTI) 2009

Seda Essential Oils Business Incubator 2006

(SEOBI) (2 Incubation Centers)

Seda Limpopo Jewellery Incubator 2009 (SLJI)

Seda Nelson Mandela Bay ICT Incubator 2008 (SNMBICTI)

Seda Northern Cape Diamond and 2012

Jewellery Incubator

Seda Platinum Incubator (SPI)

$2006 \quad 10$

3 Years

New

3 Years

Seda Sugar Cane Incubator SESUCI) 2004

Seed Container Park (Secopa)

2010

56

3 Years

No Records

3 Years

Smart Exchange

2009

No Records

3 Years

5

3 Years

SoftstartBTI (SBTI)

2006

Soshanguve Manufacturing Technology 2010

Demonstration Centre (SMTDC)

Timbali

2004

Zenzele Technology Demonstration 2003

Centre

Total

528

(Source: Author)

Table 14: Number of Graduates from Private Sector Business Incubators

\begin{tabular}{|c|c|c|c|}
\hline $\begin{array}{l}\text { Name of Private } \\
\text { Business Incubator }\end{array}$ & $\begin{array}{l}\text { Founding } \\
\text { Year }\end{array}$ & $\begin{array}{lr}\text { Number } & \text { of } \\
\text { Graduates } & \text { since } \\
\text { Inception to } 2012\end{array}$ & $\begin{array}{l}\text { Graduation } \\
\text { Period }\end{array}$ \\
\hline Raizcorp Business Incubator & 2000 & 900 & 3 years \\
\hline Aurik Business Incubator & 2001 & 800 & 1 to 3 Years \\
\hline Shanduka Black Umbrellas (JHB) & 2009 & 3 & 3 years \\
\hline Shanduka Black Umbrellas (CT) & 2008 & 4 & 3 years \\
\hline Shanduka Black Umbrellas (PTA) & 2010 & New & 3 years \\
\hline Shanduka Black Umbrellas (DBN) & 2011 & New & 3 years \\
\hline Sasol Chemcity Incubator & 2004 & 652 & 3 years \\
\hline Bandwidth Barn Incubator & 2000 & No Records & 3 years \\
\hline Maxum Business Incubator & 2005 & No Records & 3 years \\
\hline Total & & 2359 & \\
\hline
\end{tabular}


Tables 13 and 14 provide valuable information on the graduation performances of SMMEs from incubators. It is evident by comparing the two tables that the performance of private sector incubators is much more impressive as compared to the group of public sector incubators. For the group of public sector incubators from which information could be obtained, in total the number of graduates was 528 by the end of the 2012 financial year, with the largest numbers generated from the Timbali Floriculture incubator, Furntech and SEDA sugar cane incubators. By contrast, the seven surveyed private sector incubators have graduated a total of 2359 SMMEs. This means that in terms of the business incubation movement in South Africa, the small group of private sector incubators records a much greater impact than their public counterparts as indexed by graduation of SMMEs. In explaining this different performance, it should be noted, however, that private sector incubators tend to target for recruitment the group of high growth and high impact enterprises while public incubators predominately focus on small and micro enterprises. For example, SEDA incubators target SMMEs with an annual turnover around R250 000 (In 2013 \$1 = R10 South African Rand approximately). By contrast, the group of private incubators target the recruitment of enterprises with a much higher annual turnover often from R5 million and above.

Graduation is mandatory in all South African incubators. However, in most cases this rule is not strictly applied. The majority of incubators emphasize that they will only graduate an SMME once the product or service being rendered is ready for the market. Both public and private incubators stipulate three years as a generally accepted incubation period. In some cases it is possible for an SMME to exit the incubator earlier or later than the agreed three years incubation period depending on the readiness of the product or the service being rendered. The graduation of incubatees into the mainstream business environment is one of the major key performance indicators used by incubators to measure and evaluate their performance and economic impact globally (Ravjee, 2010). Nevertheless, with a few exceptions, Table 14 reveals that several public sector incubators surveyed do not maintain accurate records of the state of SMMEs that have graduated from their incubators since inception. Furntech is one of the few exceptions, having graduated 85 SMMEs since 2001. More alarming is the admission by SEDA Technology Programme (STP), the entity responsible for managing all public sector incubators in South Africa, that they do not have records about SMME graduation from their incubators. The STP is a division of SEDA which is responsible for, amongst other things, monitoring and evaluation of the performance of all public incubators. By contrast, all private business incubators kept accurate records of their graduates since inception.

\section{Conclusion}

For promoting small business development there is a growing international interest in the use of business incubation as one strategy to tackle the high mortality rates which are prevalent amongst start-up enterprises. With the critical role identified for SMMEs in South Africa for creating new employment opportunities, particularly over the next two decades, the promotion of business incubation is an issue of mounting policy concern. The expanding network of business incubators can contribute to support the SMME economy and thus be part of place-based local economic development programming (Rogerson \& Rogerson, 2010a, 2010b, 2011; Rogerson, 2014). This paper addresses the knowledge gap about business incubators in South Africa. It highlights the burst of new incubator expansion in the past decade which has been driven mainly by the activities of the country's small enterprise development agency. In addition, in common with the international experience, there has been 
a growth in South Africa of private sector involvement in the development of business incubators.

The national survey undertaken in this study reveals that in terms of the incubators, important variations exist in the landscape of private as opposed to public sector funded business incubators. It is observed that the private sector incubators are mainly mixed in focus and spatially highly concentrated in the major metropolitan centres and market areas of the country. By contrast, the pattern of public sector incubators is that mainly they are sectorally focused and geographically less concentrated in major metropolitan areas as there has been a deliberate attempt by government to locate public sector incubators in poorer provinces and secondary cities or small towns. However, the results from the survey interviews point to critical differences in the operations and impacts of the groups of public and private sector incubators as indexed by the size of incubators, recruitment strategies, graduation performance and jobs created. Overall, given their rising policy significance, further investigations are merited into the unfolding landscape and performance of small business incubators in South Africa.

\section{Acknowledgements}

Thanks are due to research funding support from the National Research Foundation, Pretoria and the University of Johannesburg. A preliminary version of this paper was presented at the Society for South African Geographers Conference, Cape Town, July 2012. The comments of referees were extremely helpful in the revision of this paper.

\section{References}

Akcomak, I.S. (2009). Incubators as Tools for Entrepreneurship Promotion in Developing Countries. Helsinki, UNU-WIDER Working Papers 2009/52.

Barbero, J.L., Casillas, J.C., Ramos, A. \& Guitar, S. (2012). Revisiting incubation performance: How incubator typology affects results, Technological Forecasting \& Social Change, 79, pp. 888-902.

Buys, A.J. \& Mbewana, P.N. (2007). Key success factors for business incubation in South Africa: The Godisa case study, South African Journal of Science, 103 (9-10), pp. 356-358.

Colombo, M. \& Delmastro, M. (2002). How effective are technology incubators? Evidence from Italy, Research Policy, 31 (7), pp. 1103-1122.

Department of Economic Development (2010) The New Growth Path Framework, Pretoria, Department of Economic Development.

DTI (1995). White Paper on National Strategy for the Development and Promotion of Small Business in South Africa, Cape Town, DTI.

DTI (2006) Integrated Small-Enterprise Development Strategy: Unlocking the Potential of South African Entrepreneurs, Pretoria, DTI.

DTI (2013). DTI launches Incubation Support Programme. Pretoria, DTI.

Fakir, E. (2009). Politics, State and Society in South Africa: Between Leadership, Trust and technocrats, Midrand, Development Bank of Southern Africa Development Planning Division Working Paper Series No.1.

Greve, N. (2014) New cabinet: thinking small. Engineering News, 6-12 June, p. 11.

Herrington, M., Kew, J., \& Kew, P. (2008). Global Entrepreneurship Monitor 2008 South African Report, Cape Town, Graduate School of Business, University of Cape Town.

Herrington, M., Kew, J., \& Kew, P. (2009). Tracking Entrepreneurship in South Africa: A GEM perspective,. London, Global Entrepreneurship Research Association.

Herrington, M., Kew, J., \& Kew, P. (2010). Global Entrepreneurship Monitor 2010 South African Report, Cape Town, University of Cape Town Graduate School of Business. 
Herrington, M., Kew, J., \& Kew, P. (2011). Global Entrepreneurship Monitor 2011 South African Report, Cape Town, University of Cape Town Graduate School of Business.

InfoDev (2010a). Global Practice in Incubation: Policy development and Implementation. Washington DC, The World Bank.

InfoDev (2010b). Global Practice in Incubation: Policy development and Implementation: South African Country Study,. Washington DC, The World Bank.

Masutha, M. (2014) Small business incubators in South Africa: Emergence, geography and local impacts, Unpublished MSc dissertation, University of Johannesburg.

Monkman, D. (2010). Business Incubators and Their Role in Job Creation, Ohio, NBIA

National Planning Commission. (2011). National Development Plan: Vision for 2030. Pretoria, National Planning Commission.

Ndabeni, L. (2008). The contribution of business incubators and technology stations to small enterprise development in South Africa. Development Southern Africa, 25, pp. 259-268.

Ndungu S.K. \& Frye I. (2008). Poverty, Inequality and Creating Decent Work, Johannesburg, National Labour and Economic Development Institute.

Ravjee, J. (2010). Critical success factors for incubators. Unpublished paper presented at the African Incubator Network, Durban.

Rogerson, C.M. (2004) The impact of the South African government's SMME programmes: a ten year review, Development Southern Africa, 21, pp. 765-784.

Rogerson, C.M. (2006) The market development approach to SMME development: Implications for local government in South Africa, Urban Forum, 17, pp. 54-78.

Rogerson, C.M. (2007) Small enterprise development in South Africa's lagging regions: the case of Mpumalanga province, Urban Forum, 18, pp. 60-93.

Rogerson, C.M. (2008a) Consolidating local economic development in South Africa, Urban Forum, 19, pp. 307-328.

Rogerson, C.M. (2008b) Tracking SMME development in South Africa: Issues of finance, training and the regulatory environment. Urban Forum, 19, pp. 61-81.

Rogerson, C.M. (2010) Local economic development in South Africa: Key strategic challenges, Development Southern Africa, 27, pp. 481-495.

Rogerson, C.M. (2011) Tracking local economic development policy and practice in South Africa, 1994-2009. Urban Forum, 22, pp. 149-168.

Rogerson, C.M. (2012) Supplier diversity: A new phenomenon in private sector procurement in South Africa. Urban Forum, 23, pp. 279-297.

Rogerson, C.M. (2013) Improving market access opportunities for urban small, medium and micro-enterprises in South Africa. Urbani izziv, 24 (2), pp. 133-143.

Rogerson, C.M. (2014) Reframing place-based economic development in South Africa: The example of local economic development. Bulletin in Geography: Socio-Economic Series, 24, pp. 203-218.

Rogerson, C.M. \& Rogerson, J.M. (2010a) Local economic development in Africa: Global context and research directions, Development Southern Africa, 27, pp. 465-480.

Rogerson, C.M. \& Rogerson, J.M. (2010b) Improving the business environment of Johannesburg, Development Southern Africa, 27, pp. 577-593.

Rogerson, C.M. \& Rogerson, J.M. (2011) Improving the business environment for local economic development in South Africa, Journal of Public Administration, 46, pp. 994-1009.

Rogerson, C.M. \& Rogerson, J.M. (2012) Business development and local economic development in South Africa: Addressing the disconnect. Acta Academica, 44 (2), pp. 41-69.

Sandheep, R. \& Thomas, W. (2011) How are South Africa's Government-subsidized small business incubators doing at nurturing start-up enterprises? Raising Businesses: Agenda, 2, pp. 18-21. 
SEDA (2010) Seda Technology Programme Incubators Fast Track SMME Success. Pretoria, SEDA.

SEDA (2011a) Incubator Support Promised for SMEs. Pretoria, SEDA.

SEDA (2011b) Annual Report 2010/11. Pretoria, Seda.

SEDA (2012) Annual Report 2011/12. Pretoria, Seda.

Timm, S. (2011) How South Africa Can Boost Support to Small Businesses: Lessons from Brazil and India, Pretoria, Trade and Industrial Policy Secretariat.

Wyeth, C. (2007) Government's Role in Supporting Innovation and Entrepreneurship in South Africa. Paper presented at the African Incubator Network Conference, Maputo, 9 July. 